\title{
ФОРМУВАННЯ ІТ-КОМПЕТЕНТНОСТІ МАЙБУТНІХ МАГІСТРІВ ЯК ПСИХОЛОГО-ПЕДАГОГІЧНА ПРОБЛЕМА
}

\section{Візнюк Інесса}

Вінницький державний педагогічний університет імені Михайла Коцюбинського,

м. Вінниця, Україна

innavisnjuk@gmail.com

ORCID : 0000-0001-6538-7742

\section{Поліщук Анна}

Вінницький державний педагогічний університет імені Михайла Коцюбинського,

м. Вінниця, Україна

anna_polishchukpas@ukr.net

ORCID: 0000-0002-0559-1087

Мета. У вступі обгрунтовано проблему інформаційної та комунікативної компетентності в наш час, що $є$ надзвичайно важливою, особливо в умовах карантину, коли нам доводиться сидіти вдома і працювати віддалено. Метою статті $є$ розробка та перевірка ефективності реалізації авторської програми для формування компетентності-IT майбутніх магістрів у галузі освіти. В цій статті йдеться про розробку та перевірку ефективності використання авторської програми для формування інформаційно-комунікативної компетентності майбутніх магістрів у галузі освіти на базі Вінницького державного педагогічного університету імені Михайла Коцюбинського.

Методи. Загальна організація та наукові дослідження проводились відповідно до встановлених вимог щодо експериментальної роботи: було сформульовано гіпотезу, заплановано експеримент відповідно до гіпотези; організовано контрольну та експериментальну групи; визначено методи та засоби, критерії експериментального дослідження доведено до відома учасників експерименту; визначено оптимальну тривалість експериментальної роботи.

Результати. На початкових етапах дослідження отримані результати довели, що в навчальних дисциплінах не було IT-змісту, тому професійна компетентність формувалася стихійно. Не вистачало розкриття змісту навчальних дисциплін підтримки IT для досліджень майбутніх учителів та освітян, оволодіння ними засобами IКТ для підвищення ефективності наукових досліджень. За результатами подальшого дослідження були розроблені критерії, показники та методи вивчення складової інформаційнокомунікативної компетентності майбутніх магістрів у галузі освіти, рівні 
сформованості дослідницької складової інформаційно-комунікаційних компетентностей майбутніх магістрів у галузі освіти та визначено поняття «хмарні технології». Запропоновано різні завдання для вивчення інформаційної та комунікативної компетентності магістра. Впроваджено авторську програму формування інформаційно-комунікативної компетентності майбутніх магістрів у галузі освіти. Зіставлено показники згаданої компетентності магістрів до і після експерименту.

Висновки. У висновках зазначено, що запропонована програма формування інформаційно-комунікативної компетентності майбутніх магістрів у галузі освіти в рамках експериментальної групи виявилася ефективною та невипадковою. Виявлено загальне збільшення показників високого та достатнього рівнів для формування дослідницької складової інформаційнокомунікативної компетентності майбутніх магістрів у галузі освіти.

Ключові слова: інформаційно-комунікативна компетентність, майбутні магістри в галузі освіти, дослідницька складова, міжнародні бази даних.

\section{Viznyuk Inessa, Polishchuk Anna. Formation of IT-competence of future masters as a psychological and pedagogical problem.}

Purpose. The introduction substantiates the problem of IT-competencies in our time, which is extremely important, especially in quarantine, when we have to sit at home and work remotely. The purpose of the article is to develop and test the effectiveness of the author's program for the formation of competence-IT of future masters in education. This article deals with the development and verification of the effectiveness of the author's program for the formation of information and communication competence of future masters in the field of education on the basis of Vinnytsia State Pedagogical University named after Mykhailo Kotsyubynsky.

Methods. The psychodiagnostic experiment is planned in accordance with the purpose and objectives of the study, control and experimental groups are organized, methods and means of experimental work are determined.In the initial stages of the study, the results proved that there was no IT content in the disciplines, so professional competence was formed spontaneously. There was a lack of disclosure of the content of IT support disciplines for research of future teachers and educators, their mastery of ICT tools to increase the effectiveness of research.

Results. Based on the results of further research, criteria, indicators and methods of studying the component of information and communication competence of future masters in education, levels of formation of the research component of information and communication competence of future masters in education were developed and the concept of "cloud technology" was defined. Various tasks for studying the information and communicative competence of the master are offered. The author's program of formation of information and communicative competence of future masters in the field of education is introduced.

Conclusions. The conclusions indicate that the proposed program for the formation of information and communication competence of future masters in the field of education within the experimental group was effective and not accidental. 
Keywords: information and communication competence, future masters in the field of education, research component, international databases.

\section{Визнюк Инесса, Полищук Анна. Формирование ИТ-компетентности} будущих магистров как психолого-педагогическая проблема.

Цель. Во введении обоснована проблема информационной и коммуникативной компетентности в наше время, что является чрезвычайно важным, особенно в условиях карантина, когда нам приходится сидеть дома и работать удаленно. Целью статьи является разработка и проверка эффективности реализации авторской программы для формирования компетентности-ИТ будущих магистров в области образования. В данной статье речь идет о разработке и проверке эффективности использования авторской программы для формирования информационно-коммуникативной компетентности будущих магистров в области образования на базе Винницкого государственного педагогического университета имени Михаила Коцюбинского.

Методы. Общая организация и научные исследования проводились в соответствии с установленными требованиями по экспериментальной работе: была сформулирована гипотеза, запланирован эксперимент согласно гипотезе; организованы контрольная и экспериментальная группы; определены методы и средства, критерии экспериментального исследования доведены до сведения участников эксперимента; определена оптимальная продолжительность экспериментальной работы. На начальных этапах исследования получены результаты доказали, что в учебных дисциплинах не было ИТ-содержания, поэтому профессиональная компетентность формировалась стихийно. $\mathrm{He}$ хватало раскрытия содержания учебных дисциплин поддержки ИТ для исследований будущих учителей и педагогов, овладение ими средствами ИКТ для повышения эффективности научных исследований.

Результаты. По результатам дальнейшего исследования были разработаны критерии, показатели и методы изучения составляющей информационнокоммуникативной компетентности будущих магистров в области образования. На уровне сформированности исследовательской составляющей информационно-коммуникационных компетенций будущих магистров в области образования и определено понятие «облачные технологии». Предложены различные задания для изучения информационной и коммуникативной компетентности магистра. Внедрена авторская программа формирования информационно-коммуникативной компетентности будущих магистров в области образования. Сопоставлены показатели данной компетентности магистров до и после эксперимента.

Выводы. В выводах отмечается, что предложенная программа формирования информационно-коммуникативной компетентности будущих магистров в области образования в рамках экспериментальной группы оказалась эффективной и неслучайной. Выявлено общее увеличение показателей высокого и достаточного уровня для формирования 
исследовательской составляющей информационно-коммуникативной компетентности будущих магистров в области образования.

Ключевые слова: информационно-коммуникативная компетентность, будущие магистры в области образования, исследовательская составляющая, международные базы данных.

Вступ. Умови модернізації освіти спонукають до пошуку нової освітньої парадигми, яка вимагає від фахівців не лише готовності розв'язувати професійні завдання, а й забезпечити використання сучасних інформаційно-комунікаційних технологій (ІКТ) для роботи з інформацією в майбутній професійній діяльності i бути мобільними в умовах інформатизації суспільства. Сучасний перекладач має самостійно ставити й розв'язувати навчально-пізнавальні завдання інформаційного пошуку, розробляти й використовувати інформаційні ресурси, IКТ як для моделювання і здійснення інноваційного освітнього процесу, так і для особистісно-професійного саморозвитку. Для розв'язання цих завдань вимагається такий розвиток особистості майбутнього перекладача, що надасть йому можливість випереджати наявну в будь-який момент часу затребуваність знань шляхом власної пізнавальної активності. Саме ці особистісні якості в інтеграції з наявними компетенціями створюють потенціал та основу для нарощування нових компетентностей, адекватних сучасному етапу розвитку інформаційного суспільства. В цьому випадку можна говорити про розвиток інформаційної компетентності студентів майбутніх фахівців-філологів.

Дистанційне навчання (ДН) - нова організація освітнього процесу, що базується на принципі самостійного навчання студента. Середовище навчання характеризується тим, що студенти в основному, а часто й повністю, віддалені від викладача у просторі й часі, водночас вони мають можливість у будь-який момент підтримувати діалог за допомогою засобів телекомунікації (Гуревич, 2015).

Дослідження виконане за допомогою обробки психопедагогічних досліджень засобами IKT (Konoshevskyi, 2011). C. Rwodzi, L. de Jager, \& N. Mpofu (2020) запропоновано інноваційне використання соціальних медіа для викладання англійської мови як другої мови. I. M. Візнюк (2019) проаналізовано особливості платформи дистанційного навчання в контексті моделі забезпечення віддаленого доступу до навчальних ресурсів в процесі підготовки майбутніх 
фахівців i розкрито особливості наявних сервісів та платформ дистанційного навчання. Використано блоги та вікі-сайти M. D. Garcia Santiago (2016) у навчанні перекладача. У працях O. B. Bihych \& V. V. Strilets (2020) розкрито переваги та недоліки засобів перекладу IКТ: бази даних перекладу (контекст Reverso); електронні словники (ABBYY Lingv., multitran), необхідні для вдосконалення та розширення словника потенційних перекладачів; електронні текстові корпуси як джерела автентичних лінгвістичних матеріалів, системи машинного перекладу (Google Translate) та засоби CAT (Trados, SmartCAT), здатні прискорити складання цільового тексту. S. T. S. Ahmed, B. T. Qasem, \& S. V. Pawar (2020) вказують на необхідність удосконалення володіння англійською мовою та включення соціальних медіа до викладання мови через те, що вчителям доводиться розробляти нові стратегії навчання, які передбачають цифрові засоби. У Міжнародному журналі мовної освіти йдеться про відсутність у навчальних закладах Південної Смені інструментів ІКТ у відділах централізованої системи, недоступність Інтернету та відсутність комп'ютерної компетентності й навчання серед викладачів. S. Bernardini (2016) засвідчує про використання засобів перекладу IКT на курсах, спрямованих на розвиток тематичних, технологічних та інформаційних навичок 3 видобутку інформації для використання їх як професійних посібників, де увага зосереджена на викладанні іноземних мов для перекладачів (надання послуг перекладу, мови та міжкультурних приміток). I. Lakić, J. Pralas (2016) впроваджували контент засобів перекладу IKT, заснований на стандартах ЕMT, які пов'язані 3 наданням послуг перекладу та інструментами CAT. I. Briales, G. Filsenger, E. Alonso (2018) відзначають важливість лексикографічних, термінологічних та документальних потреб, які зазнавали випробування під час дослідження. На відміну від професійних перекладачів, студенти-перекладачі вважають доречним використання мобільних пристроїв дуже переконливим і зручним у використанні. C. P. Lara (2019) повідомляє, що машинний переклад традиційно пов'язаний iз технологічними навичками самого перекладача. Обгрунтовано нові потреби в навчанні: віртуальні корпорації як ресурси для навчання та перекладу державних служб за підходами M. D. M. Sanchez Ramos (2017). Здійснено оцінку того, наскільки правильно перекладачі програм перекладу відповідають 
реальності професійної практики за тематичним дослідженням iспанського контексту A. Muñoz-Miquel (2018). Суть етапів формування інформаційної компетентності перекладача розкрито за пропозиціями S. M. Amelina, R. O. Tarasenko (2018). Використано електронні інформаційні ресурси C. Olalla-Soler (2018) для вирішення проблем культурного перекладу. M. Schaeffer, D. Huepe, S. HansenSchirra, S. Hofmann, E. Muñoz, B. Kogan, E. Herrera, A. Ibanez, A. M. García (2020) запропонували анкету опитування щодо правильності перекладу: онлайн-інструмент для дослідження перекладачів, яка склала основу нашого авторського опитувальника. C. Olalla-Soler (2019) застосовано інтерналізовані знання про культуру джерела для вирішення проблем культурного перекладу в квазіекспериментальному дослідженні щодо здобуття перекладачем культурної компетентності в різних мовах та культурах.

Незважаючи на низку вищезазначених наукових праць за темою дослідження, які певною мірою сприяють вирішенню зазначеної проблеми, можна констатувати, що в сучасній педагогічній науці недостатньо обгрунтовано проблему професійної підготовки майбутніх перекладачів у класичному університеті.

Основною метою експериментального дослідження є розробка та перевірка ефективності реалізації авторської програми для формування компетентності IT майбутніх магістрів у галузі освіти.

Гіпотеза дослідження полягає в тому, що результат самореалізації майбутнього перекладача $\epsilon$ продуктом його самостійної діяльності у поєднанні 3 IКТ у забезпеченні інформаційної компетентності на майбутнє.

Методи та процедура дослідження. Експериментальною основою дослідження був Вінницький державний педагогічний університет імені Михайла Коцюбинського. Експеримент проводився впродовж 2018-2020 років.

Дослідження проводили в кілька окремих етапів.

На першому етапі роботи були проаналізовані освітні програми та навчальні програми для підготовки майбутніх магістрів у вищих навчальних закладах, обрані в якості експериментальної основи. Було встановлено, що освітні навчальні програми для майбутніх магістрів у галузі освіти були розроблені, щоб надати студентам поглиблені академічні та / або професійні знання, сформувати компетентності, 
що мають важливу науково-дослідну складову, та забезпечити підготовку для наукової (магістерської) роботи.

Отримані результати довели, що в навчальних дисциплінах не було IT-змісту, тому професійна компетентність формувалася стихійно. Не вистачало розкриття змісту навчальних дисциплін підтримки IT для досліджень майбутніх учителів та освітян, оволодіння ними засобами IKT для підвищення ефективності наукових досліджень.

На другому еmani дослідження на основі аналізу наукової літератури були розроблені критерії та показники рівня сформованості дослідницької складової ІК-компетентності майбутніх магістрів у галузі освіти, відпрацьовані методи перевірки та була сформована вибірка. Вибірка складалася зі 130 магістрів педагогічних спеціальностей, серед яких 55 чоловіків та 75 жінок віком від 21 до 32 років. Вона була сформована шляхом випадкового відбору відповідно до мети дослідження.

Tpemiǔ eman дослідження включав проведення експерименту на константвальному, формувальному та контрольному етапах.

Загальна організація та наукові дослідження проводились відповідно до встановлених вимог щодо експериментальної роботи: було сформульовано гіпотезу, заплановано експеримент відповідно до гіпотези; організовано контрольну та експериментальну групи; визначено методи та засоби, критерії експериментального дослідження доведено до відома учасників експерименту; визначено оптимальну тривалість експериментальної роботи.

Методами експериментального дослідження були: педагогічне спостереження для додаткової перевірки даних, збору фактів під час дослідження; опитування (анкетування, тестування, співбесіда) для визначення рівня сформованості дослідницької складової ITкомпетентності майбутніх магістрів у галузі освіти; виконання проблемних та творчих завдань для формування IT-компетентності майбутніх магістрів у галузі освіти; статистичні методи математичної обробки експериментальних результатів для кількісного та якісного аналізу емпіричних даних. Надійність експериментальних результатів була доведена методом кореляції ознак за критерієм Пірсона $\chi^{2}$.

Були використані такі діагностичні засоби: 1) анкети (здобувачам вищої освіти запропонували авторську анкету для вивчення позиції майбутніх учених (магістрів) у галузі освіти щодо використання IT- 
підтримки для досліджень; 2) тестування. Студентам вищих навчальних закладів було запропоновано авторський тест, який включав питання для перевірки базових навичок роботи 3 комп'ютерами та програмами Microsoft Office, a також деякі спеціальні знання та навички, пов'язані 3 роботою хмарних технологій, дистанційним навчанням, візуалізацією теоретичного матеріалу, використанням мультимедіа тощо.

На констатуючому етапі експерименту за допомогою комплексу розроблених методів перевірки рівня сформованості дослідницької складової ІТ-компетентності майбутніх магістрів у галузі освіти діагностовано рівні сформованості цього компонента. Більшість респондентів мали середній та недостатній рівень. Це дало основу для авторської програми, спрямованої на формування компетенції IT, зокрема їі дослідницької складової.

Зміст цієї експериментальної програми включав наступне: залучення майбутніх науковців до активних наукових комунікацій, організації та проведення наукових заходів 3 використанням ITпідтримки; створення особистого освітнього та наукового середовища для майбутнього вченого; використання форм і методів дистанційного навчання; забезпечення майбутніх учених необхідним набором знань, умінь та навичок для роботи з хмарними сервісами, наукометричними базами даних, комп'ютерними програмами, засобами електронного навчання тощо.

Респонденти експериментальної групи (EG) взяли участь в авторській програмі формування компетентності-IT майбутніх магістрів. Вона включала систему спеціальних заходів та вправ (формуючий експеримент). Респонденти, які формували контрольну групу, працювали за традиційною програмою.

На контрольному етапі проводився статистичний аналіз експериментальних результатів для встановлення ефективності розробленої програми, що дозволило зробити висновок про ефективність запропонованої авторської програми для формування ITкомпетентності майбутніх магістрів у галузі освіти. Експеримент проводився 3 урахуванням принципів добровільності, мотивації, орієнтації на майбутню професійну та наукову діяльність. Етичні права учасників експерименту були повністю дотримані.

Обговорення результатів. На основі аналізу наукової літератури розроблено критерії та показники рівня сформованості дослідницької 
складової ІТ-компетентності майбутніх магістрів у галузі освіти. Для цього ми визначили такі критерії: мотиваційно-цінний, оперативноактивний, рефлексивний. Також було визначено методи дослідження дослідницької складової ІТ-компетентності майбутніх магістрів у галузі освіти за кожним із критеріїв (табл. 1).

\section{Таблиця 1}

Критерії, показники та методи вивчення дослідницької складової IT-компетентності майбутніх магістрів у галузі освіти

\begin{tabular}{|c|c|c|}
\hline Критерії & Показники & Методи \\
\hline $\begin{array}{c}\text { Мотиваційний } \\
\text { і ціннісний }\end{array}$ & $\begin{array}{c}\text { - формування потреби у використанні засобів } \\
\text { ІКТ для наукової діяльності; } \\
\text { - сформований інтерес та позитивне ставлення } \\
\text { до використання ІКТ у науковій діяльності; } \\
\text { - прагнення до якісного наукового спілкування } \\
\text { та успіху в науковій діяльності. }\end{array}$ & $\begin{array}{c}\text { Анкета, } \\
\text { інтерв'ю, } \\
\text { спостереження }\end{array}$ \\
\hline $\begin{array}{l}\text { Дієвий та } \\
\text { активний }\end{array}$ & $\begin{array}{c}\text { - навички та вміння працювати в IC- } \\
\text { освітньому середовищі для пошуку та } \\
\text { зберігання інформаційних даних, наукового } \\
\text { спілкування в Інтернеті, реєстрації результатів } \\
\text { досліджень із використанням IКТ; } \\
\text { - навички та вміння працювати в умовах } \\
\text { дистанційного навчання; } \\
\text { - здатність творчої діяльності до розробки та } \\
\text { впровадження електронних освітніх ресурсів, } \\
\text { презентації результатів наукових досліджень. }\end{array}$ & $\begin{array}{c}\text { Проблемно- } \\
\text { пошукові та } \\
\text { творчі } \\
\text { завдання }\end{array}$ \\
\hline Рефлексивний & $\begin{array}{c}\text { - здатність адекватно оцінювати наявні засоби } \\
\text { ІКТ та самооцінку власних можливостей і } \\
\text { перспектив використання засобів ІКТ у } \\
\text { дослідженнях; } \\
\text { - бажання підвищити власний рівень } \\
\text { компетенції ІК, прагнення до саморозвитку та } \\
\text { самовдосконалення у сфері ІКТ; } \\
\text { - готовність до освоєння інновацій у галузі ІКТ } \\
\text { для наукової діяльності. }\end{array}$ & $\begin{array}{l}\text { Аналітичне } \\
\text { завдання, } \\
\text { співбесіда }\end{array}$ \\
\hline
\end{tabular}

За результатами вимірювання динаміки рівня сформованості інформаційної компетентності майбутніх перекладачів у респондентів контрольної (CG) та експериментальної груп (EG) проводили таким чином:

- у групах CG-1 та EG-1 було проведено три типи вимірювань: вхідні (вересень 2018 р.), проміжні (червень 2019 р.) та остаточні (червень 2020 р.); 
- у групах CG-2 та EG-2, EG-3 було проведено два вимірювання: вхідне (вересень 2018 р.) та остаточне (червень 2020 р.).

Експериментальна робота, проведена для перевірки ефективності розроблених організаційно-педагогічних умов для формування інформаційної компетентності майбутніх перекладачів у професійній підготовці, стала можливою завдяки участі 130 студентів, які навчались у 2018-2019 та 2019-2020 навчальних роках у Вінницькому державному педагогічному університеті імені Михайла Коцюбинського.

Аналіз даних, отриманих у доекспериментальному розділі педагогічного експерименту (рис. 1), дозволяє 3 достатньою впевненістю зафіксувати переважання низького та середнього рівнів інформаційної компетентності майбутніх перекладачів (табл. 2).

Результати експерименту свідчать про збільшення низької мотивації до успіху з одночасним зниженням середньої та помірно високої мотивації у контрольній групі. У цій групі не відбулося суттєвих змін у шкалах «Отримання диплома», «Отримання знань» та «Оволодіння професією» в методиці «Мотивація до навчання у ЗВО».

Таблиця 2

Рівень сформованості інформаційної компетентності майбутніх перекладачів у доекспериментальному розділі

\begin{tabular}{|c|c|c|c|c|c|c|c|}
\hline \multirow{2}{*}{ Групи } & \multirow{2}{*}{$\begin{array}{c}\text { Кількість } \\
\text { людей }\end{array}$} & \multicolumn{2}{|c|}{ Низький } & \multicolumn{2}{c|}{ Середній } & \multicolumn{2}{c|}{ Високий } \\
\cline { 3 - 8 } & Кількість & $\%$ & Кількість & $\%$ & Кількість & $\%$ \\
\hline EG-1 & 97 & 49 & 50.52 & 43 & 44.33 & 5 & 5.15 \\
\hline EG-2 & 95 & 49 & 51.58 & 45 & 47.37 & 1 & 1.05 \\
\hline EG-3 & 99 & 50 & 50.51 & 45 & 45.45 & 4 & 4.04 \\
\hline EG & 291 & 148 & 50.86 & 133 & 45.70 & 10 & 3.44 \\
\hline CG-1 & 93 & 51 & 54.84 & 38 & 40.86 & 4 & 4.30 \\
\hline CG-2 & 105 & 57 & 54.29 & 43 & 40.95 & 5 & 4.76 \\
\hline CG & 198 & 108 & 54.54 & 81 & 40.91 & 9 & 4.55 \\
\hline
\end{tabular}

Експериментальні групи продемонстрували стійке зниження низької мотивації до успіху. За рівнем зацікавленості в цих групах частка респондентів із середнім та помірно високим рівнем мотивації до успіху стабільно зростала, що, згідно з інтерпретацією методології, засвідчує більшу працездатність людини. В експериментальних групах також спостерігалося зниження такої мотивації до навчання, як «Отримання диплома» 3 одночасним підвищенням мотивації «Оволодіння професією». 


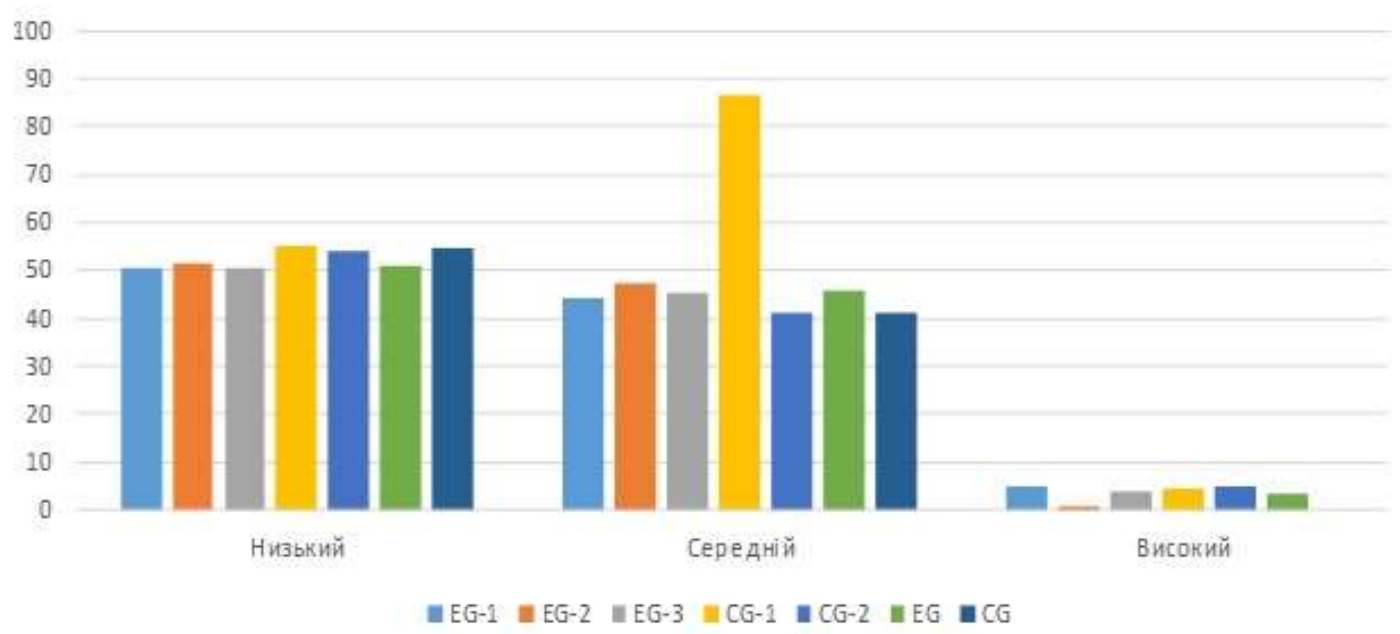

\section{Рис.1. Оцінка рівнів сформованості інформаційної} компетентності майбутніх перекладачів під час доекспериментальної секції

Використовуючи відповідні значення з таблиць за стандартною формулою для визначення критерію Пірсона, отримали числові значення за допомогою електронних таблиць Microsoft Excel 2017. Критерій $\chi^{2}$ Пірсона на рівнях значущості 0,01 та 0,05 підтвердив відсутність статистично значущих відмінностей у формуванні вихідних значень рівня інформаційної компетентності майбутніх перекладачів у професійній підготовці між експериментальними групами, оскільки менший за критичний (табл. 3) ( $\chi^{2} \mathrm{emp} \leq \chi^{2}$ crit), що дозволяє зробити висновок, що контрольна та експериментальна групи на констатуючому етапі експерименту є однорідними.

Таблиця 3

Значення емпіричного критерію Пірсона, отриманого в ході доекспериментального розділу педагогічного експерименту

\begin{tabular}{|l|c|c|}
\multicolumn{1}{|c|}{ Групи } & Розрахункове значення $\chi^{2}$ етр & \multirow{2}{*}{$\chi^{2}$ сrit на рівні значущості 0,05 } \\
\hline CG-1 \& EG-1 & 0.38 & \\
\hline CG-1 \& EG-2 & 2.82 & \multirow{2}{*}{5} \\
\cline { 1 - 2 } CG-1 \& EG-3 & 0.56 & \multirow{2}{*}{} \\
\hline CG-2 \& EG-1 & 0.39 & \\
\hline CG-2 \& EG-2 & 2.82 & \\
\cline { 1 - 2 } CG-2 \& EG-3 & 0.44 & \\
\cline { 1 - 2 } CG \& EG & 1.30 & \\
\hline
\end{tabular}

Критерій Пірсона, на рівні значущості 0,05, підтвердив, що між експериментальними групами не було статистично значущих відмінностей у формуванні вихідних значень рівня інформаційної компетентності майбутніх перекладачів у професійній підготовці 
(отже, доведено «нульову гіпотезу» $\mathrm{H}_{0}$ ), оскільки всі розраховані значення $\chi^{2}$ emp $\leq \chi^{2}$ crit, що дозволяє зробити висновок про те, що склад учнів контрольної та експериментальної груп на стадії постановки експерименту якісно рівний.

Отримані дані та їх графічна ілюстрація дозволили зробити висновок, що рівень сформованості компонентів інформаційної компетентності майбутніх перекладачів в експериментальних групах суттєво відрізняється від рівня сформованості компонентів інформаційної компетентності респондентів у контрольних групах.

Статистичні розрахунки, виконані 3 використанням критерію Пірсона, дозволили довести, що рівень сформованості компонентів інформаційної компетентності майбутніх перекладачів в експериментальних групах $є$ значним (на рівні значущості 0,05) i відрізняється від рівня сформованості компонентів інформаційної компетентності в контрольній групі.

Отримана інформація дозволяє зробити певні висновки щодо ефективності створеної методичної системи формування інформаційної компетентності майбутніх перекладачів у професійній підготовці. Діагностика рівня сформованості інформаційної компетентності майбутніх перекладачів на завершальному етапі педагогічного експерименту була проведена у травні 2020 року (рис. 2).

Під час експериментальної роботи частка респондентів, які мають низький рівень інформаційної компетентності майбутніх перекладачів, в експериментальних групах зменшилася в середньому на $22 \%$, тоді як частка тих, хто має високий рівень, зросла на $22 \%$. Середній рівень інформаційної компетентності внаслідок переходу студентів від низького до середнього та від середнього до високого залишався майже незмінним.

Експериментальні групи продемонстрували зниження зовнішньої мотивації професійної діяльності 3 одночасним підвищенням внутрішньої мотивації, відповідно, зростає важливість діяльності, спрямованої на формування інформаційної компетентності майбутніх перекладачів для особистості. 


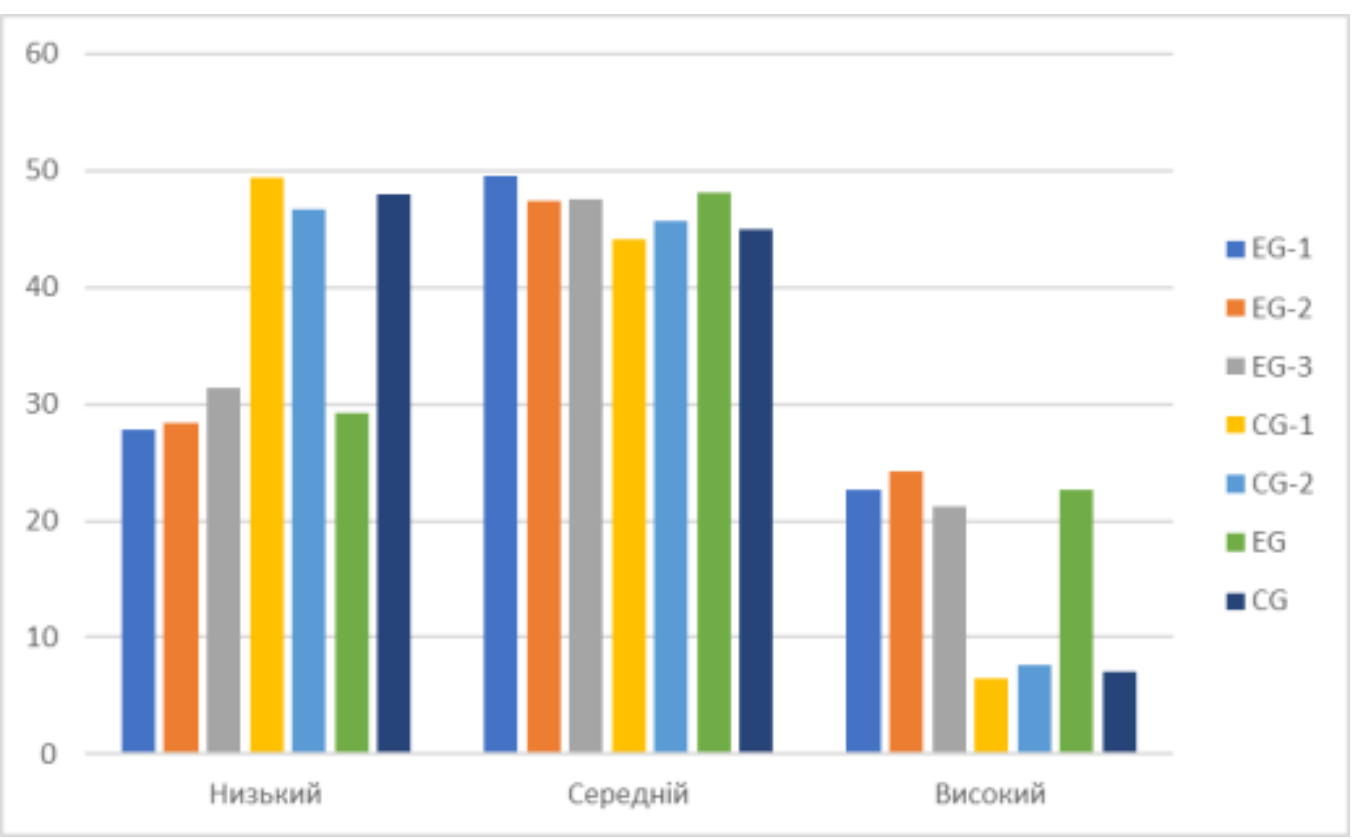

\section{Рис.2. Оцінка рівнів сформованості інформаційної компетентності майбутніх перекладачів на завершальному етапі педагогічного експерименту}

Частка респондентів, які мають оптимальний рівень значень інформаційної компетентності, також зросла з 17\% до 25\%. У процесі середній рівень значень збільшився з 22\% до 55\%.

Критерій $\chi^{2}$ Пірсона на рівнях значущості 0,01 і 0,05 підтвердив наявність статистично значущих відмінностей між експериментальними групами у формуванні значень рівня інформаційної компетентності майбутніх перекладачів у професійній підготовці (тому «нульову гіпотезу» відхиляють), оскільки всі розраховані значення (табл. 1) $\chi^{2} \mathrm{emp}$ більші за критичні: $\chi^{2} \mathrm{emp} \geq \chi^{2}$ crit. Це дозволяє прийняти альтернативну гіпотезу $\mathrm{H}_{0}$ i зробити висновок: реалізація комплексу педагогічних умов не $\epsilon$ випадковим явищем зміни рівня інформаційної компетентності майбутніх перекладачів під час професійної підготовки експериментальних груп на завершальному етапі експерименту.

Результатом самореалізації майбутнього перекладача $є$ продукт його самостійної діяльності: власне тлумачення смислової цінності навчального матеріалу, впровадження авторських модифікацій різних масштабів у рекомендовану педагогічну методологію; співтворчість, спрямована на створення нового досвіду у співпраці 3 колегами; перехід на вищий рівень володіння іноземною мовою, що, природно, необхідно для розвитку інноваційного освітнього середовища як мети професійної освіти майбутніх перекладачів. 
Отже, розроблені організаційно-педагогічні умови для формування інформаційної компетентності майбутніх перекладачів під час професійної підготовки базуються на вимогах Державних стандартів філологічної підготовки, нормативних вимогах до професійної діяльності майбутніх перекладачів, з дотриманням вимог доброчесності, відкритості, перспективності, міждисциплінарної інтеграції змісту навчання в методологічну систему, безперервності, модульності, гуманістичної спрямованості та діалогічності тощо. Саме тому етапи формування інформаційної компетентності майбутніх перекладачів розглядаються нами як особливості професійної підготовки майбутніх перекладачів у класичному університеті.

Висновки і перспективи. Визначено, що змістовною основою організаційно-педагогічних умов формування інформаційної компетентності майбутніх перекладачів у професійній підготовці $€$ багаторівневі інформаційні завдання професійної діяльності перекладачів, що створюють безперервні методологічні лінії у вивченні концепційі формуванні шляхів вирішення перекладу та інформаційні проблеми.

Доведено, що пріоритетне використання в технологічній складовій методологічної системи активних та інтерактивних методів формування інформаційної компетентності майбутніх перекладачів за допомогою сучасних засобів навчання створює умови для особистісного зростання й досвіду у виконанні перекладацьких та інформаційних завдань у діяльності професійного перекладача.

Особливості професійної підготовки майбутніх перекладачів у класичному університеті знаходять своє відображення у запроектованих організаційно-педагогічних умовах формування інформаційної компетентності майбутніх перекладачів під час професійної підготовки.

Подальші дослідження цієї проблеми включають впровадження імітаційних технологій, комп'ютерне моделювання, елементи геоінформаційних та мобільних систем, кластерні технології, порівняльний аналіз наявних зарубіжних та вітчизняних технологій для підготовки перекладачів, використання сучасних високотехнологічних інструментів, енергоефективних технологій та телекомунікацій в освіті тощо. 


\section{Література}

1. Візнюк, I. М. (2019). Впровадження ПККПТ в освітньо-інформативне середовище дистанційного навчання за програмою «Macromedia flash». Технології розвитку інтелекту, Т. 3, 3(24), 23-46.

2. Гуревич, Р. С. (2015). Формування освітнього інформаційного середовища для підготовки кваліфікованих робітників у професійно-технічних навчальних закладах: монографія. Вінниця: ТОВ фірма «Планер», 234-271.

3. Коношевський, Л. Л. Обробка психологічних досліджень засобами ІКТ: Навчально-методичний посібник. Вінниця: ТОВ Фірма «Планер», 2011. $200 \mathrm{c}$.

4. Bihych, O. B., Strilets, V. V. Potential for the use of ict in teaching scientific and technical translation (2020). Information technologies and learning tools, 76(2), 86-95. DOI: https://doi.org/10.33407/itlt.v76i2.2812.

5. Rwodzi, C., de Jager, L., \& Mpofu, N. (2020). The innovative use of social media for teaching English as a second language. TD: The Journal for Transdisciplinary Research in Southern Africa, 16(1), 702. DOI: 10.4102/td.v16i1.702.

6. Ahmed, S. T. S., Qasem, B. T., \& Pawar, S. V. (2020). Computer-Assisted Language Instruction in South Yemeni Context: A Study of Teachers' Attitudes, ICT Uses and Challenges. International Journal of Language Education, 4(1), 59-73. DOI: 10.26858/ijole.v4i2.10106.

7. Gerlin, M. N. M. Between theory and practice: the constitution of a training network for reading and information skills (2020). Revista Ibero-Americana De Ciencia Da Informacao, 13(2), 720-735. DOI: 10.26512/rici.v13.n2.2020.31682.

8. Bernardini, S. (2016). Discovery learning in the language-for-translation classroom: corpora as learning aids. Cadernos de Tradução, 36(SI), 14-35. doi: 10.5007/2175-7968.2016v36nesp1p14.

9. Lakić, I., \& Pralas, J. (2016). Translation Training for the EU: The Case of Montenegro. Current Trends in Translation Teaching and Learning E, 3(1), 87-118.

10. Garcia Santiago, M. D. (2016). The use of blogs and wikis in the training of the translator. Tradumatica-traduccio i tecnologies de la informacio i la comunicacio, (14), 147-155.

11. Sanchez Ramos, M. D. M. (2017). Emerging training needs: virtual corpora as resources for Public Service Interpreting and Translation training. Onomazein, (38), 169-187. DOI: 10.7764/onomazein.38.07.

12. Muñoz-Miquel, A. (2018). Assessing how closely postgraduate translation programmes fit the reality of professional practice: a case study of the Spanish context. The Interpreter and Translator Trainer, 12(1), 89-109. DOI: 10.1080 /1750399X.2017.1418582.

13. Amelina, S. M., \& Tarasenko, R. O. (2018). The essence of the stages of forming the information competence of the translator. Information technologies and learning tools, 67(5), 44-55. DOI: 10.33407/itlt.v67i5.2276. 
14. Olalla-Soler, C. (2018). Using electronic information resources to solve cultural translation problems. Journal of Documentation, 74(6), 1293-1317. DOI: 10.1108/JD-02-2018-0033.

15. Schaeffer, M., Huepe, D., Hansen-Schirra, S., Hofmann, S., Muñoz, E., Kogan, B., Herrera, E., Ibanez, A., \& García, A. M. (2020). The Translation and Interpreting Competence Questionnaire: an online tool for research on translators and interpreters. Perspectives - studies in translation theory and practice, 28(1), 90-108, DOI: 10.1080/0907676X.2019.1629468.

\section{References}

1. Vizniuk, I. M. (2019). Vprovadzhennia PKKPT v osvitno-informatyvne seredovyshche dystantsiinoho navchannia za prohramoiu «Macromedia flash» [Introduction of PKKPT in the educational and informative environment of distance learning according to the program "Macromedia flash".]. Tekhnolohii rozvytku intelektu, T. 3, 3(24), 23-46 [in Ukrainian].

2. Gurevich, R. S. (2015). Formation of educational information environment for the training of skilled workers in vocational schools: a monograph [Formation of an educational information environment for the training of skilled workers in vocational schools]. Vinnytsia: Planer LLC, 234- 271 [in Ukrainian].

3. Konoshevskyi, L. L. (2011). Obrobka psykholohichnykh doslidzhen zasobamy IKT: Navchalno-metodychnyi posibnyk. [Processing of psychological researches by means ICT]. Vinnytsia: TOV Firma «Planer», 200 [in Ukrainian].

4. Bihych, O. B., Strilets, V. V. Potential for the use of ict in teaching scientific and technical translation (2020). Information technologies and learning tools, 76(2), 86-95. DOI: https://doi.org/10.33407/itlt.v76i2.2812.

5. Rwodzi, C., de Jager, L., \& Mpofu, N. (2020). The innovative use of social media for teaching English as a second language. TD: The Journal for Transdisciplinary Research in Southern Africa, 16(1), 702. DOI: 10.4102/td.v16i1.702.

6. Ahmed, S. T. S., Qasem, B. T., \& Pawar, S. V. (2020). ComputerAssisted Language Instruction in South Yemeni Context: A Study of Teachers' Attitudes, ICT Uses and Challenges. International Journal of Language Education, 4(1), 59-73. DOI: 10.26858/ijole.v4i2.10106.

7. Gerlin, M. N. M. Between theory and practice: the constitution of a training network for reading and information skills (2020). Revista Ibero-Americana De Ciencia Da Informacao, 13(2), 720-735. DOI: 10.26512/rici.v13.n2.2020.31682.

8. Bernardini, S. (2016). Discovery learning in the language-for-translation classroom: corpora as learning aids. Cadernos de Tradução, 36(SI), 14-35. DOI: 10.5007/2175-7968.2016v36nesp1p14.

9. Lakić, I., \& Pralas, J. (2016). Translation Training for the EU: The Case of Montenegro. Current Trends in Translation Teaching and Learning E, 3(1), 87118. 
10. Garcia Santiago, M. D. (2016). The use of blogs and wikis in the training of the translator. Tradumatica-traduccio $i$ tecnologies de la informacio $i$ la comunicacio, (14), 147-155.

11. Sanchez Ramos, M. D. M. (2017). Emerging training needs: virtual corpora as resources for Public Service Interpreting and Translation training. Onomazein, (38), 169-187. DOI: 10.7764/onomazein.38.07.

12. Muñoz-Miquel, A. (2018). Assessing how closely postgraduate translation programmes fit the reality of professional practice: a case study of the Spanish context. The Interpreter and Translator Trainer, 12(1), 89-109. DOI: 10.1080/ 1750399X.2017.1418582.

13. Amelina, S. M., \& Tarasenko, R. O. (2018). The essence of the stages of forming the information competence of the translator. Information technologies and learning tools, 67(5), 44-55. DOI: 10.33407/itlt.v67i5.2276.

14. Olalla-Soler, C. (2018). Using electronic information resources to solve cultural translation problems. Journal of Documentation, 74(6), 1293-1317. DOI: 10.1108/JD-02-2018-0033.

15. Schaeffer, M., Huepe, D., Hansen-Schirra, S., Hofmann, S., Muñoz, E., Kogan, B., Herrera, E., Ibanez, A., \& García, A. M. (2020). The Translation and Interpreting Competence Questionnaire: an online tool for research on translators and interpreters. Perspectives - studies in translation theory and practice, 28(1), 90-108, DOI: 10.1080/0907676X.2019.1629468.

Received: 02.01.2021

Accepted: 28.01.2021 